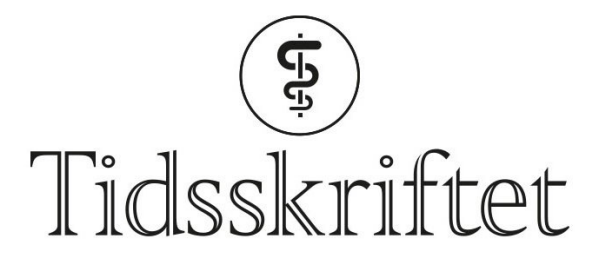

DEN NORSKE LEGEFORENING

\title{
Antidepressiver mot akutt depresjon
}

FRA ANDRE TIDSSKRIFTER

KETIL SLAGSTAD

Tidsskriftet

Antidepressive legemidler ved depresjon er mer effektive enn placebo, hevder forfatterne av en ny, stor studie. Men hva er den kliniske betydningen?

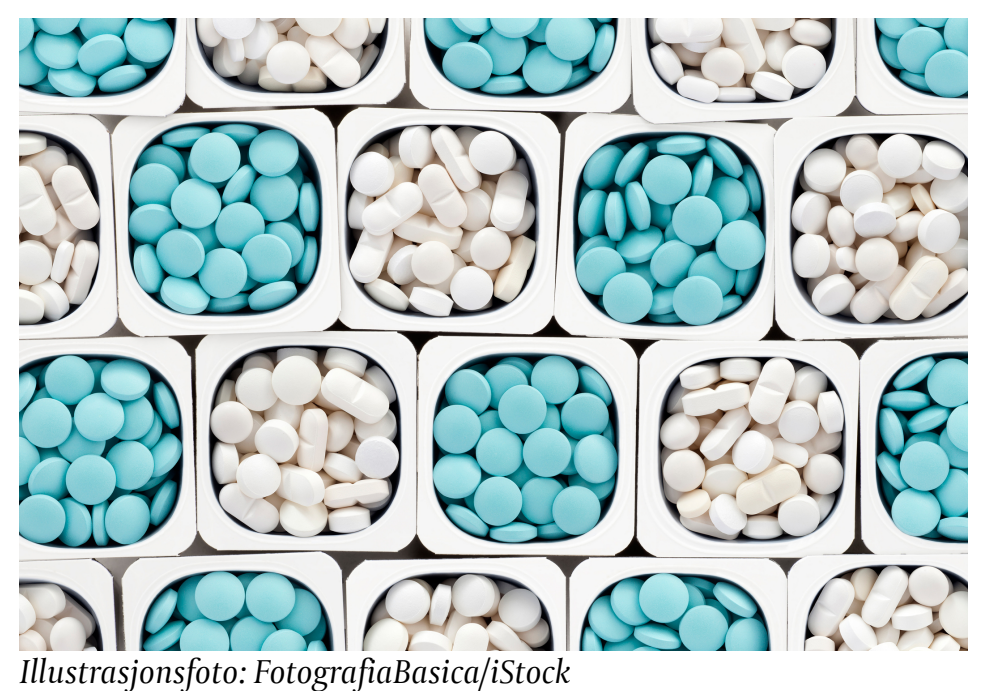

Effekten av antidepressive legemidler har lenge vært omdiskutert. En ny megastudie som nylig er publisert i tidsskriftet The Lancet (1), viste at antidepressiver er mer effektive enn placebo. Internasjonalt har dette ført til en rekke medieoppslag der man mener at debatten om legemidlenes effekt nå kan legges død. Stemmer det?

522 studier fra perioden 1979-2016 med flere enn 116 ooo pasienter og 21 ulike antidepressive legemidler ble inkludert, alle randomiserte, dobbeltblinde studier med monoterapi (med og uten placebo) for behandling av akutt moderat til alvorlig depresjon. Data fra upubliserte og pågående studier og upublisert informasjon fra legemiddelfirmaer ble innhentet i halvparten av studiene. Tilleggsmedisinering ved behov, for eksempel med benzodiazepiner og sovemedisiner, var tillatt i om lag en tredel av studiene. Nesten $80 \%$ av studiene var finansiert av legemiddelindustrien.

Alle de 21 antidepressive legemidlene var mer effektive enn placebo, vurdert som minst $50 \%$ reduksjon av totalskår på en observatørvurdert skala åtte uker etter behandlingsstart. Oddsratio for effekt varierte fra 1,15 til 1,55 og for tolererbarhet fra o,64 til o,83, men med vide konfidensintervaller. Frafall pga. bivirkninger var høyere for legemidlene enn ved placebo (oddsratio 1,64-4,44). Forskjellene mellom legemidlene var større der to legemidler ble sammenlignet mot hverandre (head-to-head-studier) enn i placebokontrollerte studier. 
Effektstørrelsene var mindre i de nye, store placebokontrollerte studiene enn i eldre og mindre studier. Risiko for seleksjonsskjevhet ble vurdert som høy i $9 \%$ og moderat i $73 \%$ av studiene. Evidensvurdering (GRADE) for amitriptylin, bupropion og venlafaksin var lav eller veldig lav, men moderat for escitalopram og mirtazapin.

- Dette er et imponerende stykke arbeid med høykompetente forskere bak, sier Arne Vaaler, som er overlege ved Psykiatrisk akuttseksjon på St. Olavs hospital og professor i psykiatri ved Norges teknisk-naturvitenskapelige universitet. Vaaler sier at studien må ses i sammenheng med en metaanalyse publisert i fjor av 131 studier med over 27 ooo pasienter om bruk av selektive serotoninreopptakshemmere (SSRI) (2). Forfatterne av den studien konkluderte med at SSRI-legemidler ikke hadde klinisk meningsfull effekt på depressive symptomer og at legemidlene $ø$ kte risikoen for alvorlige og ikke-alvorlige bivirkninger. Forfatterne av den nye metastudien mener likevel at deres funn gir grunnlag for spesifikke behandlingsvalg.

- Slik jeg vurderer resultatene, støtter de klinisk erfaring om at antidepressiver hjelper noen pasienter med depresjon. Noen pasienter blir alvorlig forverret, særlig i oppstartsfasen. Reduksjonen i depresjonsskår åtte uker etter behandlingsstart er etter min mening svært lav eller uten klinisk betydning, sier Vaaler.

- Dessuten kan antidepressive legemidler øke suicidaltanker, mens det er omdiskutert hvorvidt de øker antall selvmord. Det kan ikke understrekes nok: Etter oppstart av antidepressive legemidler må pasienten følges opp tett, i begynnelsen 2-3 ganger i uken. Antidepressive legemidler skaper avhengighet, og dosereduksjon eller seponering må skje gradvis, avslutter han.

\section{LITTERATUR:}

1. Cipriani A, Furukawa TA, Salanti G et al. Comparative efficacy and acceptability of 21 antidepressant drugs for the acute treatment of adults with major depressive disorder: a systematic review and network meta-analysis. Lancet 2018; So140-6736(17)32802-7. [PubMed][CrossRef]

2. Jakobsen JC, Katakam KK, Schou A et al. Selective serotonin reuptake inhibitors versus placebo in patients with major depressive disorder. A systematic review with meta-analysis and Trial Sequential Analysis. BMC Psychiatry 2017; 17: 58. [PubMed][CrossRef]

Publisert: 15. mars 2018. Tidsskr Nor Legeforen. DOI: 10.4045/tidsskr.18.0227

(C) Tidsskrift for Den norske legeforening 2020. Lastet ned fra tidsskriftet.no 